\title{
Rural Human Resource Management in the Background of New Rural Construction
}

\author{
Chongmei Li \\ School of Humanities, Sichuan Agricultural University, Yaan, Sichuan, \\ 625000, China
}

\begin{abstract}
At present, the peasant is the main force of our country's labour force and the rural human resource management is the most important task in agriculture and rural work, which is of great significance to the new rural construction. Therefore, we should not only pay attention to rural human resources management from the concept, but also effectively improve the quality and skills of farmers to promote rapid economic development in rural areas.

Keywords: rural human resource management, new rural construction
\end{abstract}

\section{Introduction}

CPC Central Committee 2006 on the 1st document, "the construction of a new socialist countryside is the process of modernization in China's major historical task. To accelerate the modernization drive, we must properly handle the relationship between urban and rural workers. Socialism and harmonious society, we must promote the overall economic and social progress in rural areas. The rural population is our national conditions, only the development of good rural economy, building a good farmer's home, let the peasants live a comfortable life, to protect all the people to share the economic and social development. In order to continuously expand domestic demand and promote the sustainable development of the national economy. "In our view, building a new socialist countryside must solve the problem of rural human resources, full and rational management of rural human resources. 


\section{The concept of new rural construction}

The construction of a new socialist countryside, "the development of production, well-off life, rural civilization, village renovation, management democracy," the twenty-word requirements, concisely covering the rural economy, politics, culture, social and party style construction five aspects Political, cultural and social development under the new situation, and put forward specific suggestions on how to build a new socialist countryside. The construction of a new socialist countryside, around the regional economy and competitive industries, with the purpose of increasing the income of farmers, the government as the leading to the village or farm as the basic unit to carry out "aimed at the backbone of farmers, taking into account the general farmers" training, In the agricultural technical capacity and management capacity at the same time, promote the peasant culture and ideological and moral aspects of quality improvement, to achieve the comprehensive development of rural human resources. The key to building a new socialist countryside is to give full play to the main role of the peasant masses, to mobilize the enthusiasm and creativity of the peasants, not only to make rural residents have the ability to build a new socialist countryside, but also to propagate them through various channels.

\section{The significance of rural human resources management under the background of new rural construction}

The so-called rural human resources management refers to the rural human resources in its possible management of the organic combination of space. In addition to including rural labour in the inter-industry, inter-industry, inter-and inter-season management, but also the number of rural human resources and quality matching; in the life cycle reasonable arrangements for individual human resources training and use. It is of great significance to study the rural human resource management in the context of building a new socialist countryside.

The 16th CPC National Congress put forward the grand goal of accelerating the process of industrialization and building a well-off society in an all-round way. An important indicator of a well-off society is the relative proportion of the rural population is small and the relative share of agricultural employment is low. The scientific management of rural human resources can consciously guide the transformation of social economic structure towards our goal, which will help to reduce contradictions and avoid detours in accelerating the transformation of social and economic structure.

The study of rural human resource management can improve the situation of rural human resources. For a long time, China's rural human resources idle is very obvious, and, with the scientific and technological progress is accelerating, the rural human resources idle problem will become more prominent. At the same time, there are a large number of job vacancies in certain regions, specific industries and even in certain seasons. The improvement of rural human 
resources management will undoubtedly help alleviate the situation of unemployment and vacancies. Research on rural human resource management can change the rural people "baggage" as the advantage of human resources and enhance the international competitiveness of agriculture. The agricultural international competition in the 21 st century is more brutal, and the agricultural competitive advantage of a country will be more dependent on the advantages of human resources. If we consider rural human resources as an open system, we can analyze the advantages of the system from three levels: quantitative level, quality level and management level. The number and quality level determine the overall size of the system, and the management level determines the structure of the system. China's rural human resources in the quality and management of the two levels are to be improved.

The study of rural human resource management can effectively improve the economic efficiency of rural human resources and increase the income of peasants. China's rural human resources economic efficiency is not high, there is a large number of marginal productivity is low or even close to zero phenomenon and increasing the income of farmers is difficult. By improving management, farmers can not only directly access to resource management efficiency, but also help improve the use of rural human resources, the degree of specialization and expertise to play and training.

\section{The problems of rural human resources management in the context of new rural construction}

\subsection{The farmers are not paying enough attention.}

In China's rural areas, most of the farmers to education investment is only seen as consumption, fully aware of its long-term economic benefits. Even recognize that education is an investment, but also the lack of enthusiasm. The main reason is that our country traditional agriculture, without workers with high cultural knowledge and professional training, many rural families of rural human resources management is not enough attention. Farmers' cultural quality is relatively low, which directly affects their ability to accept high technology, leading to many new varieties, new technologies in rural areas to promote slow or even impossible to promote, hinder the rapid transformation of agricultural technology into real productivity.

\subsection{Lack of investment in education funds}

Education and training is one of the most important ways of agricultural human resource management. First of all, the investment in education, the international community are based on the Government as the main investment, China also follow international practice. Since 1982, China began to implement the "hierarchical management, county-based" investment in education system, which is the unbalanced development of urban and rural education laid the foundation. 
When the grass-roots government can not guarantee the investment of rural education funds, the lack of funds will be transferred to the farmers who, the results often make rural education in trouble.

\subsection{Urban and rural education and medical resource is imbalance.}

Mainly in the education and health care, there is still a priority to contempt for the phenomenon of urban and rural areas. Rural relative urban, educational resources plaque, in rural schools, teaching facilities is still a few years or even decades ago has been in use, rural students and low classrooms bright and spacious compared to the city of teaching buildings, A far cry from. In rural adult education, the Government still did not give enough attention, the reason is not aware of adult education in today's society on the role of rural economic development. Therefore, some rural adult education institutions are basically in the halt or halt the status quo and can not be sustained.

\subsection{Labour migration is impeded.}

At present, China's rural "talent shortage" and "human resources surplus" phenomenon co-exist. The transfer of rural labour force is divided into two types: the first is the transfer between industries, that is, from the first industry to the second and the third industry transfer; the second is the usual sense of the transfer, that is, from rural to urban. The long-term dual economic structure in urban and rural areas has restricted the transfer of rural labour force, and the increase of urban unemployment has made regional transfer difficult.

\section{The path of rural human resources management in the context of new rural construction}

\subsection{Play the guiding role of government in rural human resource management}

China has already entered the market economy, rural human resource management should be in accordance with the market only invisible hand as a guide, but the role of the government is still not be underestimated, the government still plays a macro-control in the management of the role of the government from the maintenance of social equity Justice, to achieve social stability from a high degree of firmly establish the human resources is to be excavated in China the concept of a huge intellectual capital, to the masses to promote investment in human resources is the largest investment income concept. 


\subsection{Strengthen their awareness of participation in rural human resource management}

Farmers are the main body of rural human resources management. Rural human resource management is to manage the potential of farmers, so that farmers master the knowledge, and its application to production. moral beliefs, behavioural norms, etc., affect the behaviour of workers choice. Therefore, farmers should first strengthen their ideological and moral construction, the formation of modern civilization. Establish a "male students as good as a woman" and other ideas, so that the basic national policy of family planning fell to reality. Increase farmers' income and narrow the gap between urban and rural areas, farmers should establish and strengthen the "science and technology are primary productive forces" consciousness, automatically invest in science and technology and education, embarked on the road to technology to get rich.

\subsection{Encourage farmers to multi-channel employment and entrepreneurship}

As soon as possible so that farmers change the traditional concept of business, increase market awareness of competition. It is particularly important for the peasants to in still knowledge of the market economy. Farmers with skills can work as salespersons, cooks, electricians, carpenters, cargo couriers and maintenance workers. Update job search methods and ways. Today, microblogging recruitment, job hunting has become the latest recruitment, candidates platform, the survey shows that the recruitment of micro-blogging job information far more than job seekers resume, indicating employers thirst for mercy, and earlier accepted the micro Bo recruited this new thing. To the rural labour force universal agricultural environmental protection, pest and disease control knowledge for the industrialization of agriculture and rural urbanization to provide personnel protection. At present, the "Sunshine Project", "Green Certificate" and other farmer training projects implemented by the government play a key role in improving their scientific and technological quality.

\subsection{Strengthen the cultural construction of rural residents}

From the perspective of social education, vigorously develop the CYL Committee as a leader, with outstanding youth party members as the backbone, to carry out members of the cultural tutorials, cultural and sports activities, health education and other activities, to establish the people learning, lifelong learning new rural wind, Stimulate farmers to consciously invest in rural human resources management. While carrying on cultural education, we should pay attention to the cultural construction of various forms, fully combine the traditional culture with the modern culture, combine the popular culture with the elegant culture, combine the foreign culture with the local culture, absorb the culture suitable for the broad masses Of the distinctive cultural activities and cultural projects. 


\section{Conclusion}

China is a large agricultural country, rural population is huge, rural human resources management is an arduous system engineering and its outcome largely determines the income level of peasants and the whole national economy development potential. Therefore, it is necessary to carry out in-depth study and rational conception of rural human resources management in theory, but also enrich and improve in practice.

\section{References}

[1] Zhao Jianmei. New rural construction in the rural areas of human resources development analysis. East China Economic Management, 55(12), pp.68-70, 2011

[2] Ding Xuhui. Human capital development: the transfer of rural surplus labor force strong support. 8 (5), pp.87-91, 2013

[3] Jiang Su-fen. Analysis on the Influencing Factors and Countermeasures of Rural Human Resources Development. Talent in China, 12(10), pp. 18- 20, 2012

[4] Li Qi. At this stage the development of rural human resources problems and solutions. Agricultural Economics, 8(4), pp.85-87, 2014

[5] Chen Liping. On the Development of Rural Human Resources in China. Journal of Commodities and Quality, 9(6), pp.58- 61, 201 